Cortain foodstuffs are now required by law to include vitamin $A$, and regulations require that foodstuffs, claiming to contain vitamins, be labelled in units. Manufacturers who to-day handle vitamin A are dependent on the spectroscopic method of assay using the extinction coefficient at 325-328 mu as a linear function of vitamin A activity, and it has boen necessary to adopt a factor to relate the spectroscopic reading with the biological international unit. Such factors have become standardized in Great Britain and in America although at different levels.

$\mathrm{N}$. T. Gridgeman, in "The Estimation of Vitamin A" (Lever Brothers and Unilever, Ltd., 74 ; 1944), assembles and reviews the evidence. He shows that these factors do not rest on a sound scientific basis, due mainly to the occurrence of a number of vitamin A congeners and to the fact that the biological test is very complex ; for example, there is the synergism of vitamins $\mathrm{A}$ and $\mathrm{E}$. $\mathrm{He}$ recommends the, adoption of a new unit based on the spectroscopic assay mothod. A provisional skeleton definition would be "the unit of vitamin $\mathbf{A}$ is that quantity which made up to $100 \mathrm{ml}$. with a specified organic solvent gives a solution having an extinction coefficient at $325 \mathrm{mu}$ of 0.005 ". He adds that "the quest for a new easily messurable physiological criterion of response, sharply graded to increasing dosage, prophylactic or therapeutic, of vitamin A, can be regarded as a fruitful research problem".

\section{Stars of the Southern Skies}

Leaflet No. 188 (Oct. 1944) of the Astronomical Society of the Pacific, by Leon E. Salaneve, gives a simplified star chart and guide to observations with the unaided eye and with field-glasses. It has been compiled in response to numerous requests, from the South Pacific in particular, for star finders, constellation guides, etc., and is specially designed for a latitude $20^{\circ}$ south of the equator. Only those stars are shown which are necessary to suggest the constellation figures, and after learning these the observer's knowledge can be extended with the aid of more complete charts. There is a brief description of the constellations, stars of the first magnitude, and of a few interesting objects such as the Great Nebula in Orion, the Large Magellanic Cloud, etc. The Leaflet will serve a useful purpose for those engaged in military operations who have found themselves under unfamiliar skies.

\section{Association of British Zoologists}

THE Association of British Zoologists, which had not met since January 1939 owing to the War, held its tenth annual general meeting on March 24 in the rooms of the Zoological Society of London. Proceedings opened with a business meeting during the course of which the following elections were made or, having been made by the Oouncil, were confirmed : President, Prof. James Ritchie; Hon. Secretary, Dr. John Smart, British Museum (Natural History), London, S.W.7 ; New Members of Council, Prof. D. L. Mackinnon, Prof. James Gray, Mr. J. C. F. Fryer, Prof. C. H. O'Donoghue and Wing-Commander F. S. Russell ; New Trustees, Mr. J. T. Saunders and Dr. W. E. Swinton. After the business meeting, the Association proceeded to a discussion on the "Post-War Teaching of Zoology in Schools and Universities". This discussion was opened by Dr. C. F. A. Pantin and is reported elsewhere in this issue (see p. 535). In the afternoon, a series of four shorter discussions centring around the general topic of "Some Developments of Post-War Research" was engaged in. The first, on "Marine Investigations", was opened by Dr. E. S. Russell and this was followed by one on "The Work of the Zoological Society" opened by Dr. S. A. Neave. Mr. J. C. F. Fryer opened the next, on "Zoological Interests of the Agricultural Research Council", and the final topic was "Freshwater Investigations", opened by Dr. E. B. Worthington.

\section{Frank B. Jewett Research Fellowships}

Frve Frank B. Jewett Fellowships for research in the physical sciences have been awarded by the American Telephone and Telegraph Co. to Dr. Elliot R. Alexander, Dr. Albert S. Eisenstein, Dr. Kenneth Greisen, Dr. Boris Leaf and Dr. Harry Pollard. The availability of these men to accept their fellowships will depend upon the progress of the War, as each is now engaged in essential war research. Dr. Alexander is at present a research chemist at the du Pont Experimental Station at Wilmington; Dr. Eisenstein is a member of the Radiation Laboratory staff at Cambridge, Mass. ; Dr. Greisen is engaged in war work at Santa Fé, New Mexico; Dr. Leaf is an associate chemist in the Metallurgical Laboratory of the University of Chicago; and Dr. Pollard is a member of the Applied Mathematics Group at Columbia University.

\section{Announcements}

THE following appointments have recently been made in the Colonial Services: D. Sturdy, senior agricultural officer, Tanganyika, to be director of agriculture, Jamaica; E. T. Ward, agricultural superintendent, Windward Islands, to be agricultural officer, Tanganyika ; R. K. Hardy, assistant government chemist, Nigeria, to be government chemist, Nigeria ; D. R. Rosevear, senior assistant conservator of forests, Nigeria, to be conservator of forests, Nigeria.

THE following appointments have been made to the technical staff of Ashe Laboratories, Ltd., 120/2, Victoria Streot, London, S.W.I : Mr. D. I. Duveen now takes charge of the development of full-scale production of amino-scids and protein digests; he has worked in Paris and in London and has published papers, some in collaboration with Dr. J. Kenyon, on problems connected with optical activity and the preparation and isolation of substituted naphthacenes and their photo-oxides. Mr. Duveen will be assisted by Mr. E. G. Hatten, formerly of Glaxo Laboratories, who has had experience in the production of fine chemicals and therapeutic preparations. Mr. H. S. Young, formerly with Messrs. Crosse and Blackwell and C. and E. Morton, Ltd., has been appointed food chemist and will be responsible for the control and development of food preparations manufactured by the Ashe Laboratories. Mr. P. Lewis Smith, iormerly with Messrs. Eli Lily and Co., has been appointed to the pharmaceutical section, where bis long experience in the Far East will be of great assistance in the company's export programme. The new appointments will be under the general direction of Dr. W. E. Gaunt, who is known for his work on amino-acids and protein digests.

ERratum.-The new insecticide described in the communication entitled "Acaricidal Property of a New Insecticide, Hexachlorobenzene" printed in Nature of March 31, p. 393, was wrongly named. The substance referred to is benzene-hexachloride, or $1: 2: 3: 4: 5: 6:$ hexachlorocyclohexane. 